\title{
Implementasi Manajemen Kurikulum Dalam Upaya Meningkatkan Mutu Santri Pondok Pesantren Hidayatullah/Panti Asuhan Anak Soleh Curup
}

\author{
Irwan Fathurrochman \\ Sekolah Tinggi Agama Islam Negeri Curup \\ inhamna@gmail.com
}

Abstract : Pesantren is faced with many challenges, including the modernization of Islamic education. The system and institutional pesantren have been modernized and adapted to the demands of development, especially in the institutional aspects that will automatically influence the determination of the curriculum that refers to the institution's institutional goals. The problem that arises is whether the pesantren in determining the curriculum must be merged with the demands of the present day, or rather it should be able to defend it as a characteristic of pesantren which in many ways is more able to actualize its existence in the midst of the demands of society. The curriculum is the most noticed system. Similarly, curriculum management is the first step in running it. According to Dinn Wabyudin in general the functions of curriculum management, among them: 1) improve the efficiency of resource utilization of the curriculum; 2) improve justice and opportunity to students to achieve maximum results; 3) improve the relevance and effectiveness of learning in accordance with the needs of learners and the environment around the students; 4) improve the effectiveness of teacher performance as well as student activities in achieving learning objectives; 5) improve the effectiveness and efficiency of teaching and learning process; 6) increase community participation to help develop. Pondok Pesantren Hidayatullah / Panti Asuban Anak Soleh Curup applies conventional curriculum management combined with execution of curriculum of ministry of culture education and kuriukulum ministry of religion.

Key Words : Curriculum Management, Pesantren.

\begin{abstract}
Abstrak : Pesantren dihadapkan pada banyak tantangan, termasuk di dalamnya modernisasi pendidikan Islam. Sistem dan kelembagaan pesantren telah dimodernisasi dan disesuaikan dengan tuntutan pembangunan, terutama dalam aspek kelembagaan yang secara otomatis akan mempengarubi penetapan kurikulum yang mengacu pada tujuan institusional lembaga tersebut. Persoalan yang muncul adalab apakah pesantren dalam menentukan kurikulum harus melebur pada tuntutan zaman sekarang, atau justru ia harus mampu mempertahankannya sebagai ciri khas pesantren yang dalam banyak hal justru lebih mampu mengaktualisasikan eksistensinya di tengah-tengah tuntutan masyarakat. kurikulum merupakan sistem yang paling diperhatikan. Begitu pula, manajemen kurikulum menjadi langkah awal dalam menjalankannya. Menurut Dinn Wabyudin secara umum fungsi manajemen kurikulum, di antaranya: 1) meningkatkan efisiensi pemanfaatan sumber daya kurikulum; 2) meningkatkan keadilan dan kesempatan kepada siswa untuk mencapai hasil yang maksimal; 3) meningkatkan relevansi dan efektivitas pembelajaran sesuai dengan kebutuhan peserta didik maupun lingkungan sekitar peserta didik; 4) meningkatkan efektivitas kinerja guru maupun aktivitas siswa dalam mencapai tujuan pembelajaran; 5) meningkatkan efektivitas dan efisiensi proses belajar mengajar; 6) meningkatkan partisipasi masyarakat untuk membantu mengembangkan. Pondok Pesantren Hidayatullah / Panti Asuban Anak Soleh Curup menerapkan manajemen kurikulum konvensional yang dikombinasikan dengan pelaksanaan kurikulum kementerian pendidikan kebudayaan dan kuriukulum kementerian agama.
\end{abstract}

Kata Kunci :Manajemen Kurikulum, Pesantren. 


\section{A. Pendahuluan}

Pesantren menurut pengertian dasarnya adalah tempat belajar para santri. Sebagai lembaga pendidikan Islam, pesantren dikatakan sebagai tempat belajar yang otomatis menjadi pusat budaya Islam yang disahkan atau dilembagakan oleh masyarakat, setidaknya oleh masyarakat Islam sendiri yang secara de facto tidak dapat diabaikan oleh pemerintah. Itulah sebabnya Madjid (1997:3) mengatakan bahwa dari segi historisitas, pesantren tidak hanya identik dengan makna ke-Islaman, tetapi juga mengandung makna keaslian Indonesia (indegenous) ${ }^{1}$. Pesantren maupun madrasah merupakan realisasi upaya pembaharuan sistem pendidikan Islam, yaitu upaya penyempurnaan sistem pesantren ${ }^{2}$. Penyempurnaan sistem ini sangat dipengaruhi oleh pola pendidikan pesantren maupun karakteristik yang dimiliki pesantren, seperti pesantren model klasik (salafy) ataupun pesantren modern (khalafy) atau model terpadu dari keduanya (pesantren plus).

Tujuan pendidikan pesantren adalah membentuk manusia yang memiliki kesadaran tinggi bahwa ajaran Islam membicarakan tiga masalah pokok, yaitu Tuhan, manusia dan alam setelah dikotomi mutlak antara Tuhan (khaliq) dengan makhluk, termasuk bentuk-bentuk hubungan antara ketiga unsur tersebut- yang bersifat menyeluruh. Selain itu produk pesantren diharapkan memiliki kompetensi tinggi untuk mengadakan responsif terhadap tantangan dan tuntutan hidup dalam konteks ruang dan waktu yang ada.

\footnotetext{
${ }^{1}$ Nurcholis Madjid. Bilik-bilik, pesantren. (Jakarta: Paramadina, 1997), hal. 3

${ }^{2}$ Steenbirink, Karel A. Pesantren madrasah sekolah. (Jakarta: LP3ES, 1986), hal.25
} 
Dewasa ini pesantren dihadapkan pada banyak tantangan, termasuk di dalamnya modernisasi pendidikan Islam. Sistem dan kelembagaan pesantren telah dimodernisasi dan disesuaikan dengan tuntutan pembangunan, terutama dalam aspek kelembagaan yang secara otomatis akan mempengaruhi penetapan kurikulum yang mengacu pada tujuan institusional lembaga tersebut. Persoalan yang muncul adalah apakah pesantren dalam menentukan kurikulum harus melebur pada tuntutan zaman sekarang, atau justru ia harus mampu mempertahankannya sebagai ciri khas pesantren yang dalam banyak hal justru lebih mampu mengaktualisasikan eksistensinya di tengah-tengah tuntutan masyarakat.

Dalam perkembangan masyarakat sekarang ini, dituntut adanya pembinaan peserta didik yang dilaksanakan secara berkeseimbangan antara nilai dan sikap, pengetahuan, kecerdasaan, keterampilan, kemampuan berkomunikasi dan berinteraksi dengan masyarakat luas, serta peningkatan kesadaran terhadap alam lingkungannya. Asas pembinaan semacam inilah yang seharusnya ditawarkan oleh pondok pesantren sebagai lembaga pendidikan agama Islam tertua di Indonesia, agar tetap dilihat bahkan ketika modernitas dan iptek cenderung semakin maju.

Dalam kaitannya dengan manajemen; tidak dapat dibantah lagi bahwa manajemen merupakan aspek penting yang menyentuh, mempengaruhi dan bahkan merasuki seluruh aspek kehidupan manusia; karena dengan manajemen dapat diketahui kemampuan dan kelebihan serta dapat dikenali kekurangan suatu 
organisasi. Manajemen menunjukkan cara efektif dan efisien dalam pelaksanaan suatu pekerjaan. Manajemen dapat mengurangi hambatan dalam pencapaian tujuan serta memberikan prediksi dan imajinasi agar segera mengantisipasi dengan cepat perubahan lingkungan. Demikian pula halnya dengan dunia pendidikan; maka peranan manajemen pendidikan sangat menentukan arah dan tujuan pendidikan. Pidarta merumuskan; manajemen pendidikan adalah aktivitas memadukan sumber-sumber pendidikan agar terpusat dalam usaha untuk mencapai tujuan pendidikan yang telah ditentukan sebelumnya. Sementara Tilaar berpendapat bahwa manajemen pendidikan adalah mobilisasi segala sumberdaya pendidikan untuk mencapai tujuan pendidikan yang telah ditetapkan. Manajemen pendidikan merupakan serangkaian kegiatan proses kerjasama suatu organisasi pendidikan dalam pencapaian tujuan yang wilayah pembahasannya sangat luas ${ }^{3}$.

Salah satu komponen penting pada lembaga pendidikan formal yang digunakan sebagai acuan untuk menentukan isi pengajaran, mengarahkan proses mekanisme pendidikan, tolokukur keberhasilan dan kualitas hasil pendidikan, adalah kurikulum. Namun demikian, kurikulum seringkali tidak mampu mengikuti kecepatan laju perkembangan masyarakat. Oleh karena itu, pengembangan dan pembenahan kurikulum harus senantiasa dilakukan secara berkesinambungan.

\footnotetext{
${ }^{3}$ E. Mulyasa, Kurikulum Tingkat Satuan Pendidikan, (Bandung: Remaja Rosdakarya, 2007).Hal. 224
} 
Istilah kurikulum sebagaimana halnya lembaga pendidikan formal, tidak didapat pada pondok pesantren. Kecuali jika yang dimaksud sebagai manbaj (arah pembelajaran tertentu), maka pondok pesantren telah memiliki "kurikulum" melalui funun kitabkitab yang diajarkan pada para santri. Menurut Amir Hamzah, seperti dikutip Hasbullah; muatan manhaj pesantren lebih terkonsentrasi pada ilmu-ilmu agama, semisal sintaksis Arab, morfologi Arab, hukum Islam, sistem yurisprodensi Islam, hadits, tafsir, Al-Qur an, teologi Islam, tasawuf, tarikh.

\section{B. Kajian Pustaka}

\section{1) Implementasi Manajemen Kurikulum}

Terdapat lima prinsip yang harus diperhatikan dalam melaksanakan manajemen kurikulum, yaitu sebagai berikut :

a) Produktivitas, hasil yang akan diperoleh dalam kegiatan kurikulum merupakan aspek yang harus dipertimbangkan dalam manajemen kurikulum. Pertimbangan bagaimana peserta didik dapat mencapai hasil belajar sesuai dengan tujuan kurikulum harus menjadi sasaran dalam manajemen kurikulum.

b) Demokratisasi, pelaksanaan manajemen kurikulum harus berdasarkan demokrasi yang menempatkan pengelola, pelaksan dan subjek didik pada posisi yang seharusnya dalam melaksanakan tugas dengan penuh tanggung jawab untuk mencapai tujuan kurikulum.

c) Kooperatif, untuk memperoleh hasil yang diharapkan dalam kegiatan manajemen kurikulum perlu adanya kerja sama yang positif dari berbagai pihak yang terlibat. 
90 | TADBIR : Jurnal Studi Manajemen Pendidikan, Vol. 1, No. 01, 2017

d) Efektivitas danefisien, rangkaian kegiatan manajemen kurikulum harus mempertimbangkan efektivitas dan efisiensi untuk mencapai tujuan kurikulum sehingga kegiatan manajemen kurikulum tersebut memberikan hasil yang berguna dengan biaya, tenaga, dan waktu yang relatif singkat.

e) Mengarabkan visi, misi, dan tujuan yang ditetapkan dalam kurikulum, proses manajemen kurikulum harus dapat memperkuat dan mengarahkan visi, misi, dan tujuan kurikulum ${ }^{4}$.

Sistem pendidikan Indonesia menganut asas urgensi kurikulum, yakni kurikulum merupakan sistem yang paling diperhatikan. Begitu pula, manajemen kurikulum menjadi langkah awal dalam menjalankannya. Menurut Dinn Wahyudin secara umum fungsi manajemen kurikulum, di antaranya: 1) meningkatkan efisiensi pemanfaatan sumber daya kurikulum; 2) meningkatkan keadilan dan kesempatan kepada siswa untuk mencapai hasil yang maksimal; 3) meningkatkan relevansi dan efektivitas pembelajaran sesuai dengan kebutuhan peserta didik maupun lingkungan sekitar peserta didik; 4) meningkatkan efektivitas kinerja guru maupun aktivitas siswa dalam mencapai tujuan pembelajaran; 5) meningkatkan efektivitas dan efisiensi proses belajar mengajar; 6) meningkatkan partisipasi masyarakat untuk membantu mengembangkan.

Perencanaan Kurikulum Terkait dengan fungsi operasional manajemen kurikulum yang dapat peneliti simpulkan dari berbagai uraian pengertian dan ruang lingkup manajemen

\footnotetext{
${ }^{4}$ Oemar Hamalik, Manajemen Pengembangan Kurikulum, (Bandung: Remaja Rosdakarya,2007), hal.18
} 
kurikulum di atas bahwa, fungsi manajemen kurikulum tersebut dijalankan melalui ruang lingkup manajemen kurikulum, yakni melalui perencanaan kurikulum, organisasi kurikulum, implementasi kurikulum, dan evaluasi kurikulum. Perencanaan kurikulum adalah perencanaan kesempatankesempatan belajar yang dimaksudkan untuk membina siswa ke arah perubahan tingkah laku yang diinginkan dan menilai hingga mana perubahan-perubahan telah terjadi pada diri siswa/peserta didik. Kurikulum adalah semua pengalaman yang mencakup yang diperoleh baik dari dalam maupun dari luar lembaga pendidikan ${ }^{5}$.

Pelaksanaan kurikulum pesantren, seorang guru dalam melaksanakan pembelajaran untuk dapat mengadopsi atau mengadaptasi teori-teori pembelajaran dari teori yang digunakan dengan teori yang baru, yang salah satunya sebagaimana tertuang dalam peraturan Menteri Pendidikan Nasional No 22 Tahun 2006 tentang Standar Isi (SI) sebagai berikut:

a) Pelaksanaan kurikulum didasarkan pada kompetensi, perkembangan dan kondisi santri untuk menguasai kompetensi yang berguna bagi dirinya. Dalam hal ini santri harus mendapatkan pelayanan pendidikan yang bermutu, serta memperoleh kesempatan untuk mengekspresikan dirinya secara bebas, dinamis dan menyenangkan.

b) Kurikulum dilaksanakan dengan menegakkan kelima pilar belajar, yaitu: (1) belajar untuk beriman dan bertakwa kepada Tuhan Yang Maha Esa; (2) belajar untuk memahami dan menghayati; (3)

\footnotetext{
${ }^{5}$ Rusman, Manajemen Kurikulum, (Jakarta: PT Raja Grafino Persada, 2009), hal. 3
} 
belajar untuk mampu melaksanakan dan berbuat secara efektif; (4) belajar untuk hidup bersama dan berguna bagi orang lain; dan (5) belajar untuk membangun dan menemukan jati diri, melalui proses pembelajaran yang efektif, aktif, kreatif, dan menyenangkan.

c) Pelaksanaan kurikulum memungkinkan santri mendapat pelayanan yang bersifat perbaikan, pengayaan, dan/atau percepatan sesuai dengan potensi, tahap perkembangan, dan kondisi santri dengan tetap memperhatikan keterpaduan pengembangan pribadi santri yang berdimensi ketuhanan, keindividuan, kesosialan, dan moral.

d) Kurikulum dilaksanakan dalam suasana hubungan santri dan pendidik yang saling menerima dan menghargai, akrab, terbuka, dan hangat dengan prinsip tut wuri handayani, ing madyo mangun karso, ing ngarso sung tulodo (di belakang memberikan daya dan kekuatan, di tengah membangun semangat dan prakarsa, di depan memberikan contoh dan teladan). ${ }^{6}$

Implementasi kurikulum adalah sebagai suatu proses penerapan ide, konsep, dan kebijakan kurikulum (kurikulum potensial) dalam suatu aktivitas pembelajaran, sehingga peserta didik menguasai seperangkat kompetensi tertentu, sebagai hasil interaksi dengan lingkungan. Dalam implementasi ini, tentu saja harus diupayakan penanganan terhadap pengaruh faktor-faktor tertentu, misalnya kesiapan sumber daya, faktor budaya masyarakat, dan lain-lain. Berbagai dimensi implementasi

\footnotetext{
${ }^{6}$ Permendiknas No 22/2006, Lampiran, 3 (Jakarta: Depdinas, 2006).
} 
kurikulum yang penting untuk dicermati adalah materi kurikulum dan struktur organisasi kurikulum. Peranan atau perilaku, pengetahuan, dan internalisasi nilai. Keberhasilan implementasi terutama ditentukan oleh aspek perencanaan dan strategi implementasinya. ${ }^{7}$

Menurut Binti Maunah implementasi kurikulum merupakan proses guru/staf pengajar melaksanakan kurikulum (kurikulum yang sudah ada) dalam situasi pembelajaran di kelas (sekolah, universitas/institusi dan sebagainya). Dalam bukunya juga dikatakan bahwa implementasi kurikulum adalah proses aktualisasi kurikulum potensial menjadi kurikulum aktual oleh guru/staf pengajar di dalam proses belajar mengajar (perkuliahan). Implementasi kurikulum berlangsung dalam kurun waktu terjadinya interaksi antara sistem kurikulum dan sistem instruksional. Pada titik ini kurikulum menjadi acuan kerja bagi para guru dalam mengembangkan strategi instruksional yang berarti pula saat pesan-pesan dari perencanaan kurikulum dikomunikasikan dan diinterpretasikan untuk para siswa. ${ }^{8}$

Dinn Wahyudin berpendapat bahwa implementasi mencakup tiga kegiatan pokok, yaitu pengembangan program, pelaksanaan pembelajaran, dan evaluasi. Begitu juga, faktor-faktor yang mempengaruhi implementasi kurikulum terdiri atas tiga: a) Karakteristik kurikulum, yang mencakup ruang lingkup bahan ajar, tujuan, fungsi, sifat, dan sebagainya; b) Strategi implementasi,

\footnotetext{
${ }^{7}$ Suharsimi Arikunto \& Lia Yuliana, Manajemen Pendidikan, (Yogyakarta: Aditya Media, 2008), hal. 131

${ }^{8}$ Zainal Arifin, Konsep dan Model Perkembangan Kurikulum, (Bandung :PT Remaja Rosdakarya, 2011), h. 23-26.
} 
yaitu strategi yang digunakan dalam implementasi kurikulum; c) Karakteristik penggunaan kurikulum, yang meliputi pengetahuan, keterampilan, serta nilai dan sikap guru terhadap kurikulum dalam pembelajaran. Terkait dengan implementasi kurikulum yang berbasis pada kompetensi (KBK dan KTSP) dikembangkan dengan berorientasi kepada pengembangan kepribadian (kurikulum humanistik), menuju kepada kurikulum yang berorientasi pada kehidupan dan alam pekerjaan (rekonstruksi sosial dan teknologi).

Sementara Mulyasa menjabarakan bahwa pelaksanaan kurikulum perlu memperhatikan hal-hal sebagai berikut: a) Pembelajaran harus lebih menekankan pada praktek, baik di laboratorium maupun di masyarakat dan dunia kerja (dunia usaha). Dalam hal ini setiap guru harus mampu memilih serta menggunakan strategi dan metode pembelajaran yang memungkinkan peserta didik mempraktekkan apa-apa yang dipelajari. b) Pembelajaran harus dapat menjalin hubungan lembaga dengan masyarakat; dalam hal ini setiap guru harus mampu dan jeli melihat berbagai potensi masyarakat yang bisa didayagunakan sebagai sumber belajar, dan menjadi penghubung antara madrasah dengan lingkungannya. c) Perlu dikembangkan iklim pembelajaran yang demokratis, dan terbuka melalui pembelajaran terpadu. d) Pembelajaran perlu lebih ditekankan pada masalah-masalah aktual yang secara langsung berkaitan dengan kehidupan nyata yang ada di masyarakat. e) Perlu dikembangkan suatu model pembelajaran "moving class", untuk setiap bidang studi, dan kelas merupakan laboratorium untuk 
masing-masing bidang studi, sehingga dalam satu kelas dilengkapi dengan berbagai fasilitas dan sumber belajar yang diperlukan dalam pembelajaran tertentu, serta peserta didik bisa belajar sesuai dengan minat, kemampuan, dan tempo belajar masing-masing. ${ }^{9}$

Sedangkan menurut Oemar Hamalik dalam bukunya, pelaksanaan kurikulum dalam lembaga pendidikan dibagi menjadi dua tingkatan yaitu pelaksanaan kurikulum tingkat sekolah dan kurikulum tingkat kelas. Dalam tingkat sekolah yang berperan adalah kepala sekolah dan pada tingkat kelas yang berperan adalah guru. Walaupun dibedakan antara tugas kepala sekolah dan tugas guru dalam pelaksanaan kurikulum serta diadakan perbedaan tingkat dalam pelaksanaan administrasi, yaitu tingkat kelas dan tingkat sekolah, namun antara kedua tingkat dalam pelaksanaan administrasi kurikulum tersebut senantiasa bergandengan dan bersama-sama bertanggung jawab melaksanakan proses administrasi kurikulum. ${ }^{10}$

sehingga dapat penulis ambil kesimpulan bahwa ruang lingkup manajemen kurikulum adalah pelaksanaan prinsippronsip proses manajemen itu sendiri. Hal ini dikarenakan dalam proses pelaksanaan kurikulum mempunyai titik kesamaan dalam prinsip proses manajemen, sehingga di dalam pelaksanaan kurikulum harus mengadakan pendekatan dengan ilmu manajemen.

\footnotetext{
${ }^{9}$ E. Mulyasa (ibid) Hal. 140

${ }^{10}$ Oemar Hamalik, (ibid) hal.45
} 


\section{2) Mutu Santri}

Meningkatkan mutu santri tidak lain adalah meningkatkan mutu peserta didik, dalam hal ini maka proses yang dilaksanakan berpedoman kepada pembelajaran kompetensi, sehingga santri memiliki daya saing dan menjadi bermutu dalam kualitas pembelajaran dan kualitas implementasi nilai-nilai dalam kehidupan. ${ }^{11}$

Pengembangan kurikulum pesantren pada dasarnya tidak terlepas dari visi pembangunan nasional yang berupaya menyelamatkan dan memperbaiki kehidupan nasional yang tertera dalam garis besar hukum Negara. Oleh karena itu pengembangan tersebut hendaknya mengakomodasi tuntutan-tuntutan sistematik (Depdiknas, Depag).

Secara konseptual, sebenarnya lembaga pesantren potimis akan mampu memenuhi tuntutan reformasi pembangunan nasional di atas dapat dibangun melalui perubahan kurikulum pesantren yang berusaha membekali peserta didik untuk menjadi subjek pembangunan yang mampu menampilkan keunggulan dirinya yang tangguh, kreatif dan profesional pada bidangnya masing-masing.

Realitas menunjukan pada saat ini lembaga pesantren telah berkembang secara bervariasi baik dilihat dari segi isi (kurikulum) dan bentuk/manajemen/struktur organisasi. Hasan Basri (Dalam Nata, 2001:120-121) mengembangkan lembaga non formatif ini kedalam lima pola, yakni: 1) pesantren yang hanya terdiri dari

\footnotetext{
${ }^{11}$ Sulthon \& Khusnurdilo, Manajemen Pondok Pesantren, (Jakarta: Diva Pustaka, 2005), hal. 91.
} 
masjid dan rumah kiai; 2) pesantren yang terdiri dari masjid, rumah kiai, dan asrama atau pondok; 3) pesantren yang terdiri dari masjid, rumah kiai, pondok, dan madrasah; 4) pesantren yang terdiri dari masjid, rumah kiai, pondok, madrasah dan tempat keterampilan; dan 5) pesantren yang terdiri dari masjid, rumah kiai, pondok, madrasah, tempat keterampilan, universitas, gedung pertemuan, tempat olahraga dan sekolah umum.

\section{Metode Penelitian}

Metode penelitian yang digunakan dalam pemecahan permasalahan yang ditemukan di lingkungan kerja yang disusun berdasarkan metode Penelitian Lapangan (Field Research) dengan menggunakan pendekatan kualitatif deskriptif. Metode ini adalah suatu penelitian yang ditujukan untuk mendeskripsikan dan menganalisis fenomena, peristiwa, aktivitas sosial, pemikiran orang secara individual maupun kelompok. Beberapa deskripsi digunakan untuk menemukan prinsip-prinsip dan penjelasan yang mengarah pada penyimpulan. Penelitian kualitatif bersifat induktif: peneliti membiarkan permasalahan-permasalahan uncul dari data untuk interpretasi. Dari segi kerangka teori, dalam penelitian ini, peneliti juga menggunakan pendekatan ilmu manajemen. Pendekatan ilmu manajemen merupakan pendekatan yang melihat dari sudut pandang manajemen yang akan mengarahkan pembahasan penelitian. Dalam artian, peneliti mengkaitkan pengelolaan kurikulum dengan teori manajemen, yakni menggunakan tahapan-tahapan fungsi manajemen yang telah dikenal, yang meliputi: perencanaan, pengorganisasian, implementasi, dan evaluasi. Dengan begitu, peneliti melakukan 
penelitian di Pondok Pesantren Hidayatullah Curup terkait implementasi manajemen kurikulum dalam meningkatkan mutu santri ditinjau dari sudut pandang manajemen kurikulum yang dilaksanakan.

Data dihimpun dengan pengamatan yang seksama, mencakup deskripsi dalam konteks yang mendetail disertai catatan-catatan hasil wawancara yang mendalam serta hasil analisis dokumen dan catatan-catatan. dari metode yang dipilih ini dapat dituangkan dengan mengemukakan rumusan masalah sebagai berikut :

\section{1) Rumusan masalah}

a) Bagaimanakah implementsi manajemen kurikulum dalam meningkatkan mutu Santri di Pondok Pesantren Hidayatullah / Panti Asuhan Anak Soleh Curup?

b) Bagaimanakah Pondok Pesantren Hidayatullah / Panti Asuhan Anak Soleh Curup menerapkan peningkatan mutu santri dalam meningkatkan daya saing di era ekonomi global saat ini?

\section{2) Solusi penyelesaian masalah}

Menghadapi rumusan masalah tersebut di atas, maka penulis memperoleh data hasil penelitian yang kemudian di jabarkan dalam solusi penyelesaian sebagaimana dijabarkan berikut :

\section{a) Implementasi Manajemen Kurikulum}

Sebagai salah satu bentuk ikhtiar meningkatkan mutu santri pada Pondok Pesantren Hidayatullah / Panti Asuhan Anak Sholeh 
Curup Kabupaten Rejang Lebong Provinsi Bengkulu maka implementasi prinsip-prinsip Kurikulum Tingkat Satuan Pendidikan (KTSP) telah digariskan sebagai standard dan pedoman pengajaran dan pembelajaran. pada Pondok Pesantren Hidayatullah / Panti Asuhan Anak Sholeh Curup Kabupaten Rejang Lebong, yang mana implementasi tersebut ditekankan kepada : (1) prinsip relevansi. Secara internal bahwa kurikulum memiliki relevansi diantara komponen-komponen kurikulum (tujuan, bahan, strategi, organisasi, dan evaluasi). Sedangkan secara eksternal. Komponen-komponen tersebut memiliki relevansi dengan tuntutan ilmu pengetahuan dan teknologi; (2) prinsip fleksibilitas. Dalam pengembangan kurikulum mengusahakan agar yang dihasilkan memiliki sifat luwes, lentur, dan fleksibel. Dalam pelaksanannya. Memungkinkan terjadinya penyesuaian-penyesuaian

\section{b) Meningkatkan Mutu Santri Pesantren Hidayatullah / Panti Asuhan Anak Sholeh Curup}

Kurikulum Pondok Pesantren Hidayatullah / Panti Asuhan Anak Sholeh Curup Kabupaten Rejang Lebong senantiasa mengacu pada pengertian yang luas, sehingga bisa meliputi kegiatan-kegiatan intra-kurikuler maupun ekstra-kurikuler, dan bisa melibatkan di samping aktivitas yang diperankan oleh santri juga diperankan oleh Asatdidz. Demikian juga kegiatan-kegiatan yang memiliki bobot wajib diikuti maupun sekadar anjuran termasuk liputan kurikulum.

Pemaknaan kurikulum dalam pandangan para ahli pendidikan telah mengalami pergeseran secara horizontal. 
Kurikulum dipahami sebagai sejumlah mata pelajaran di sekolah yang harus ditempuh untuk mendapat ijazah atau tingkat, maka sekarang pengertian tersebut berusaha diperluaskan. Kurikulum yang dimaksudkan adalah segala sesuatu usaha yang ditempuh sekolah untuk memengaruhi belajar, baik berlangsung di dalam kelas dan di halaman sekolah, maupun di luar kelas. Kurikulum pesantren dalam wacana selanjutnya senantiasa mengacu kepada pengertian yang luas, sehinga bisa meliputi kegiatan-kegiatan intra-kurikuler maunpun ekstra-kurikuler, dan bisa melibakan disamping aktivitas yang diperankan santri juga diperankan oleh para Pengasuh / Asatidz.

Dengan variasinya kurikulum yang dilaksanakan oleh Pondok Pesantren Hidayatullah / Panti Asuhan Anak Sholeh Curup Kabupaten Rejang Lebong, maka selanjutnya pesantren Hidayatullah secara khusus konsentrasi kepada memunculkan keahlian tidak hanya dibidang keagamaan, tetapi juga pada bidang pertanian, koperasi dan berbagai bidang life skill lainnya yang menunjang mutu santri sehingga dapat memiliki daya saing dalam menghadapi ekonomi global, khususunya menghadapi Masyarakat Ekonomi Asean (MEA) yang menjadi tantangan pada pondok pesantren serta tantangan bagi lembaga pendidikan pada umumnya.

\section{Simpulan dan Rekomendasi}

Setelah melakukan penelitian tentang Implementasi Manajemen Kurikulum Dalam Upaya Meningkatkan Mutu Santri Pondok Pesantren Hidayatullah / Panti Asuhan Anak Soleh Curup diperoleh kesimpulan bahwa Pondok Pesantren 
Hidayatullah / Panti Asuhan Anak Soleh Curup Kabupaten Rejang Lebong menerapkan manajemen kurikulum konvensional yang dikombinasikan dengan pelaksanaan kurikulum kementerian pendidikan kebudayaan dan kuriukulum kementerian agama, yang mana pelaksanaanya didasarkan kepada peraturan Menteri Pendidikan Nasional No 22 Tahun 2006, sebagaimana berikut :

a) Pelaksanaan kurikulum didasarkan pada kompetensi, perkembangan dan kondisi santri untuk menguasai kompetensi yang berguna bagi dirinya.

b) Kurikulum dilaksanakan dengan menegakkan kelima pilar belajar, yaitu: (1) belajar untuk beriman dan bertakwa kepada Tuhan Yang Maha Esa; (2) belajar untuk memahami dan menghayati; (3) belajar untuk mampu melaksanakan dan berbuat secara efektif; (4) belajar untuk hidup bersama dan berguna bagi orang lain; dan (5) belajar untuk membangun dan menemukan jati diri, melalui proses pembelajaran yang efektif, aktif, kreatif, dan menyenangkan.

c) Pelaksanaan kurikulum memungkinkan santri mendapat pelayanan yang bersifat perbaikan, pengayaan, dan/atau percepatan sesuai dengan potensi yang dimiliki.

d) Kurikulum dilaksanakan dalam suasana hubungan santri dan pendidik yang saling menerima dan menghargai, akrab, terbuka, dan hangat.

Berdasarkan simpulan diatas, maka dapat disampaikan rekomendasi Dalam implementasi manajemen kurikulum Pondok Pesantren Hidayatullah / Panti Asuhan Anak Soleh Curup 
102 | TADBIR : Jurnal Studi Manajemen Pendidikan, Vol. 1, No. 01, 2017

Kabupaten Rejang Lebong diperlukan upaya adalah dengan melaksanakan langkah-langkah berikut :

a) meningkatkan efisiensi pemanfaatan sumber daya kurikulum;

b) meningkatkan keadilan dan kesempatan kepada siswa untuk mencapai hasil yang maksimal;

c) meningkatkan relevansi dan efektivitas pembelajaran sesuai dengan kebutuhan peserta didik maupun lingkungan sekitar peserta didik;

d) meningkatkan efektivitas kinerja guru maupun aktivitas siswa dalam mencapai tujuan pembelajaran;

e) meningkatkan efektivitas dan efisiensi proses belajar mengajar; 6) meningkatkan partisipasi masyarakat untuk membantu mengembangkan.

\section{E. Daftar Pustaka}

Enco Mulyasa, Kurikulum Tingkat Satuan Pendidikan, Bandung : Remaja Rosdakarya, 2007.

Nurcholis Madjid. Bilik-bilik pesantren. Jakarta : Paramadina, 1997.

Oemar Hamalik, Manajemen Pengembangan Kurikulum, Bandung : Remaja Rosdakarya, 2007.

Permendiknas No 22/2006, Lampiran 3, Jakarta: Depdinas, 2006.

Steenbirink, Karel A. Pesantren madrasah sekolah. Jakarta : LP3ES, 1986. 
Suharsimi Arikunto \& Lia Yuliana, Manajemen Pendidikan, Yogyakarta : Aditya Media, 2008.

Sulthon \& Khusnurdilo, Manajemen Pondok Pesantren, Jakarta : Diva Pustaka, 2005.

Zainal Arifin, Konsep dan Model Perkembangan Kurikulum, Bandung : PT Remaja Rosdakarya, 2011. 
104 | TADBIR : Jurnal Studi Manajemen Pendidikan, Vol. 1, No. 01, 2017

This page belongs to the TADBIR : Jurnal Studi Manajemen Pendidikan TADBIR : Jurnal Studi Manajemen Pendidikan vol. 1, no 01, 2017

STAIN Curup - Bengkulu | p-ISSN 2580-3581; e-ISSN 2580-5037 